\title{
Optimizing Growth of Toddler Children Through Nutrition Counseling
}

\author{
Nataliningsih \\ Faculty of Agriculture \\ University of Winayamukti \\ Bandung, Indonesia \\ natalihuseina@gmail.com
}

\begin{abstract}
In Bandung district, toddler with status less body weight as much as 10355 toddlers $(3.72 \%)$ and who experienced very less weight $(<2.5 \mathrm{~kg})$ is as much as 810 toddlers $(0,25 \%)$. Therefore, need for nutrition counseling. Research is done by qualitative approach using $Q$ short method. The aim research is to know the type of nutrition education needed by integrated service post (commonly called Posyandu) managers in Bandung district. Q-short results followed up with counseling on 81 posyandu managers, is a representative of posyandu managers from 31 sub districts. The result of need assessment showed that nutritional counseling needed were knowledge of toddler growth $(28,39 \%)$, processed milk substitute feed (26,54\%) and disciplined pregnant mother and toddler came to Posyandu ( $22.22 \%$ ). The result of the research shows that there is an increase of post nutrition nutrition knowledge which is average result of pretest value is 43,57 whereas average result of posttest is 76,28 so that there is increase of knowledge equal to $32,71 \%$. Skill required by posyandu manager that is processing mother's milk substitute food namely liquid food, soft food and cookies of beans supplemented by rice bran as source of vitamin B1, while to discipline the presence of toddlers and pregnant women is made "Control Card" so that more orderly come to Posyandu in order to support policy ' Healthy Village ".
\end{abstract}

Keywords - method of $Q$ short, posyandu manager, breastmilk substitute, control card, peanut cookies

\section{INTRODUCTION}

The growth of the child begins in the womb, since the baby therefore the government policy through integrated service post (commonly called Posyandu) program, monitor the development of pregnant mother up to 5 years old baby child, in order to improve nutritional status, monitor growth and monitor health. Posyandu is managed by Family Welfare Development (PKK) mothers whose meetings are conducted once a month in Posyandu posts, with a minimum agenda of weight weighing, height measurement, arm circumference, pregnant women examination, and if there are government programs such as vaccination performed simultaneously with the monitoring. Family Welfare Development, abbreviated PKK, is a community organization that empowers women to participate in the development of Indonesia. As resource persons, sometimes posyandu managers bring Midwives or Doctors from the nearest Public Health Centers (Puskesmas).

Protein is a nutrient that is needed in the growth of toddlers, chemically, the type of protein is divided into essential and non-essential protein and animal and vegetable protein. Protein deficiency results in underfive nutritional status, less intake of daily needs to make children less susceptible to nutrition. In the year 2017 in Bandung District, the number of toddlers is 278,173 under five years old, with status less body weight as much as 10,355 toddlers, or $3,72 \%$ and who experience very less weight is as much as 810 toddlers or $0,25 \%$ (source of Bandung District Health Office, 2017). Toddlers with weight less nutritionally prone, prone to disease, and if the toddler lacks protein then can experience marasmus and khuarshiorkor, the long-term impact is the quality of human resources to be low. Nutrients and growth factors regulate brain development during fetaland early postnatal life.

Micronutrient malnutrition remains one of the largest nutritional problems worldwide, affecting people in both developed and developing countries. Children are particularly vulnerable to micronutrient deficiency owing to their high nutrient requirements for growth and susceptibility to infectious diseases such as diarrhoea andrespiratory infections, which can inhibit nutrient absorptionas well as decrease appetite. The nutrient density of the diet given to young children is often insufficient to meet their nutrient requirements, and increasing the diversity of foods provided to young children, particularly meat,poultry, fish, eggs, fruits and vegetables, is recommended to improve micronutrient intakes [1].

Therefore, health, nutritional status of children under five must be monitored through Posyandu. To facilitate the posyandu manager then made KMS (Card Towards Healthy) which form is a graph sheet which is the intersection between body weight and height consisting of three parts, namely the curve under the red color means malnutrition status, then the yellow color means to get ready begin to experience growth and green color means very healthy toddler. This kind of health monitoring is very simple and easy for Posyandu managers.

For toddlers the main consumption is protein as a builder, forming new cells or replacing damaged cells. Adequate nutrition is necessary from the beginning, with the formationof the neural plate and neural tube affected bynutrients such as folic acid, copper, and vitamin A. Seven weeks after conception, cell division begins within the neural tube, creating nerve cells (neurons) and glial cells (cells that support neurons). After a neuron is created, it migrates to its place in the brain, where it then grow saxons and dendrites projecting out from its cell body. These branching projections make connections with other cells, called synapses, through which nerve signals travel from one cell to another [2].

Children under 5 years fail to reach their potential in cognitive development because of poverty, poor health and 
nutrition, and deficient care [4]. The discrepancy between their current developmental levels and what they would have achieved in a more nurturing environment with adequate stimulation and nutrition indicates the degree of loss of potential [3].

Based on the results of the nutrition program activities in 2016 , it can be seen from the coverage of monthly growth monitoring result at posyandu that is the scope of community participation to bring the toddlers to come and be weighed in posyandu (D / S coverage) has not reached the target of $81,7 \%$ (target 2016 equal to $87 \%$ ), while the data of nutrition status of balita is very thin (malnutrition) year 2016 equal to $0,039 \%$ (as many as 107 children) when compared to year 2015 there is decrease equal to $0,003 \%$ as well as toddler stunting year 2016 equal to $6,80 \%$ decrease $2,09 \%$. Most of the malnutrition cases are malnourished due to the pattern of care and lack of knowledge and skill of mother toddler on how to feed her child.It is certainly necessary to deliver information to mothers who have a toddler about healthy food for their children (Source Bandung District Health Office, 2017). From this problem it is necessary to think about appropriate nutrition counseling given to the posyandu managers in order to decrease the number of children under five who suffer from malnutrition and nutrient prone.

\section{MATERIAL AND METHOD}

The research was conducted by qualitative approach using Q-short method. The aim of this research is to know the type of nutritional counseling needed by Posyandu managers in Bandung district, by first inviting each district to be represented by 3 Posyandu managers. Bandung regency consists of 31 sub districts, with a total attendance is 81 people. The results of the analysis using the Q-short method, followed by counseling on Posyandu managers. The instruments used were questionnaires, pre test and post test .

\section{RESULTS AND DISCUSSION}

\section{A. Needs Analysis Process}

Needs analysis activities conducted at the District Health Office of Bandung, by first inviting each district to be represented by 3 Posyandu managers. Bandung regency consists of 31 sub districts, with a total attendance is 81 people. The needs analysis activities are assisted by health department staff, with the following stages:

\section{Requirements Analysis Phase}

Participants were given a $10 \mathrm{X} 10 \mathrm{Cm}$ paper size to write down the perceived problems during Posyandu management. The results are collected and analyzed there are 6 main problems that is 1) discipline pregnant mother and toddler come to Posyandu, 2) knowledge about preparing menu for toddler, 3) processing food for toddler as substitute of milk, 4) build healthy village, 5) knowledge about growth toddlers and 6) knowledge of cultivation of plants to meet family needs.

2. Stage method Q short

Conducted by giving the marbles to each participant as much as 2 points, then selected 3 main problems that are very important to be followed by the way that is on the table placed 6 glasses as a symbol of 6 problems. Each participant is given the opportunity to put the marbles into the glass problem according to the perceived problems, then selected 3 glasses of the most problem marbles. The results of $\mathrm{Q}$ short indicate important issues that are followed up, namely knowledge of the growth of 46 children (28.39\%), milk substitute feeding of 43 marbles $(26.54 \%)$ and discipline pregnant women and toddlers coming to Posyandu with 36 marbles $(22,22 \%)$.

\section{Preparation of the Follow-up Action Plan}

Following the participatory extension phase, after obtaining the needs analysis, the preparation of Follow-Up Action Plan (RTL) is needed to carry out the activities to solve the problems faced by the Posyandu managers. The results of the agreed follow-up plan are:

a) Develop education and training schedule as follows:

- August 2018 Tuesday the second week of training, growth of toddlers

- September 2018 on Tuesday of the second week, Demonstration of milk substitute food processing

- October 2018 on Tuesday the second week, training discipline pregnant women and toddlers come to Posyandu.

b) Speaker needs done by bringing in sources

c) Financial needs are done by donating each sub-district after the calculation of the cost requirements of the three activities.

d) Each delegate of each sub-district prepares a draft report and is willing to disseminate to each village all the results of this activity.

The results of the preparation of the follow-up plan is a series of activities undertaken to answer the main problems faced by the posyandu managers in Bandung regency.

\section{B. Increased Knowledge of Growth of Toddlers}

The activity of knowledge improvement of toddlers growth is the main problem faced by the posyandu management. This happens because the question often arises from the mothers about how to make their children healthy, so that their children are smart, so that their children are active and so on, so for this activity a day training invites competent resource persons to discuss the growth of toddlers with the following materials:

1) Toddler brain development : Brain development is complex and ongoing throughout childhood and adolescence, with a time course that varies depending on the outcome considered. Parts of the neural tube are developed just 5 weeks after conception, and development of the cortex is evident by midgestation [4]. The weight of the brain is related to body weight, big people have bigger brains than small people. The task of the brain controls the most complex body functions, the brain is one of the first organs to grow before birth. Three weeks after the fertilization of the egg, the neural tube begins to form, with the nerve ends expanding and emerging three lumps. The first lump becomes the cerebrum, the place of 
intelligence and the senses, and the thalamus, the center of the relay of messages. The second lump will become the midbrain, which is a collection of nerve fibers that serve as a bridge to connect various parts of the brain. The third lump grows into a cerebellum, which controls muscle movements, pons (bridges), connecting nerves to different parts of the brain, and the medulla oblongata (controlling marrow) that controls its own functions of respiration, blood circulation, and digestion. According to Gandhel C. and Simons C [5], brain development is very rapid in toddlers, ie at age 1 year the weight rose to 700 grams, at age 2 years to 900 grams, at age 3 years to 1100 grams, at the age of 4 years became 1200 grams, at the age of 5 years to 1250 grams and after a human adult brain weight between 1300-1400 grams, because the growth of the brain in infancy is very important to optimize.

Optimizing the growth of toddler's brain can be done by fulfilling protein requirement every day in amount and type needed that is at age 0-6 month as much as 10 gram and when aged 4-6 years protein requirement a day is 110 gram. Complete protein is an animal protein, contains both essential and non essential amino acids and has a high biological value, therefore it is recommended that children more often be fed with animal protein dishes. Breast feeding until the age of 2 years is one of the fulfillment of protein needs for the body of a toddler, brain defects due to lack of protein during toddlers can not be fixed.

Cognitive development is influenced by many factors, includ- ing nutrition. There is an increasing body of literature that suggests a connection between improved nutrition and optimal brain function. Nutrients provide building blocks that play a criti- cal role in cell proliferation, DNA synthesis, neurotransmitter and hormone metabolism, and are important constituents of enzyme systems in the brain Brain development is faster in the early years of life com- pared to the rest of the body Since rapid brain growth occurs during the first 2 years of life (and by the age of 2 the brain reaches $80 \%$ of its adult weight), this period of life may be particularly sensitive to deficiencies in diet [6].

2) The development of toddlers body: Knowledge of the development of toddlers is needed by the posyandu managers, because they often get the question, when the baby is born healthy, it turns out in its development so autistic, so hyperactive, experiencing undesirable abnormalities. According to Gandhel C. and Simons C [5], at the age of 20 days the baby begins to stare at bright light or color, at the age of 1 month the baby starts to say "ah, oh" and smile, at the age of 2 months the baby starts staring at his own hands and sucking fingers, at the age of 3 months the baby can hold and shake the toy, at the age of 4 months then the baby moves his head staring at others. At the age of 5 months, the baby begins to lift his head, stuck his arms, at the age of 6 months then the baby can sit, at 7 months of age the baby can crawl, at 8-9 months old baby can grasping spoon, food, at the age of 10-11 months the baby can stand, walk while holding on to the object and the age of 12 months the baby can walk.The development of infant weight at birth, weight between $2.7-3 \mathrm{~kg}$, at the age of
1 year weight 7.5 years, at the age of $1-3$ years weigh $13.4 \mathrm{~kg}$ and when aged 4-6 years weighs $20.2 \mathrm{Kg}$. To optimize the movement and weight of toddlers, the food sources of energy substances, source of builders and sources of regulating substances are needed in the appropriate quantities and types.

The government's policy of consuming 4 healthy 5 perfect is in order to optimize optimum growth. As expected, cognitive, language, and behavioral concerns are more likely to be identified as the infant develops into toddlerhood, when there are greater expectations of the child and more-complex and more frequent interactions with the outside world than duringthe early months. Therefore, although we controlled for the age of the children at the time of examination,caregivers of toddlers were more likely to report that the children were at developmental risk than were caregivers of younger infants. In addition, birth weight, health,and gender are factors that were found in many other studies to influence development, particularly for children living in poverty, depending on the developmental outcome measured. Consistent with the work of others,children in this sample who had low birth weights, had been previously hospitalized, and were male were more likely to be at developmental risk than were children who had normal birth weights, had not been hospitalized,and were female. Caregivers who were notborn in the United States and caregivers who were employed were less likely to report that their children wereat developmental risk than were caregivers in the contrasting groups.During the first 3 years of life, when brain growth israpid,In a time of limited resources, providing nutritional and developmental interventions to young children and their families is aproactive step that might decrease the need for later,more-extensive interventions for developmentally orbehaviorally impaired children of school age [7].

\section{Food Processing Training of Breast Milk Substitute (MPASI)}

Breast Milk (ASI) is the perfect food for babies, according to Bayu [8], Gold standard of children's intake is at 0-6 months of age only breastfed, age 6 months starting MPASI with $30 \%$ MPASI balance, ASI 70\%, age $7-8$ months of nutritional fulfillment with the balance MPASI $40 \%$ breast milk $60 \%$, age 9-12 months balance 50\% breastfeeding and 50\% MPASI, at age 12-24 month balance 70\% MPASI and 30\% milk, and more 24 month $100 \%$. At this time, on the market many sold in the form of ready-to-eat food, but the content of food additive can affect the growth of physical and brain development of the baby, therefore need training MPASI training is natural.

The result of the observation to the participants shows that they are not yet know and skilled in processing the MPASI. Therefore, the training is a demonstration of 3 types of MPASI namely the processing of filtered food, soft foods and processing of peanut cookies [9]. Processing of liquid food according Nataliningsih [10], raw material filtered food that is $250 \mathrm{ml}$ fresh milk, cornstarch 20 grams, ati chicken 1 seed, half egg grains. Raw food raw material that is 50 grams of rice, ati chopped 1 seed, grated carrots 25 grams, 25 grams of chopped tomatoes. Processing of nuts cookies with red bean flour raw materials: green beans: peanut tolo: rice bran at a ratio of 30 : 
30: 30: 10.Cow's milk is not recommended during the first 12 months of life.10,11 However, fortifiedcow's milk is an important dietary componentof a toddler's diet because of its high quality protein, calcium, and vitamins Aand D. Calcium is involved in bone growth,tooth development, and muscle contraction, and it may play a role in the regulation ofblood pressure and body fat. One study showed thatchildren who consumed milk with the noontime mealwere the only group to meet or exceed 100 percent of thedaily Dietary Reference Intake for calcium (i.e., 500 to $800 \mathrm{mg}$ ). Two or three servings of milk or dairy productsper day are recommended to meet these requirements.14 Some toddlers are poorly weaned from a nall-milk diet and consume more than the recommended number of servings; this "milk diet" is high in fat andtotal calories and inadequate in iron [11].

According to WHO, exclusive breast-feeding is generally adequate for the first 6 mo of life . Thereafter, mother's milkalone cannot be expected to provide all the micronutrientsneeded for the growing infant. Nutrients that have been identified as potentially "problematic" for breastfed infants after6 mo of age are iron, zinc, vitamin A, and vitamin B-6. VitaminB-6 concentration in milk is influenced by the maternal diet, so ifthe mother's diet is adequate, the milk concentrations are likelyto be adequate.Iron and zinc are critical for immune function, neurocognitivedevelopment, and postnatal growth. As noted above, milk concentrationsof these micronutrients are relatively resistant to the maternal diet. Hence, the breast-fed infant is particularly dependenton complementary foods containing iron and zinc after6 mo of age. Without consistent intake of these micronutrients from complementary foods or other sources, the infant maydevelop physiologic manifestations of micronutrient deficiency [12].

\section{Training on Increasing Motivation of Pregnant Women and Toddlers come to Posyandu}

The result of the agreement during the training on increasing the motivation of pregnant mother and toddler to come to Posyandu is by making "Control Card" which contains the attendance table to the next posyandu, as well as the information that need to be recorded in the card, next as the note below given additional if not attending to posyandu then as punishment is visited home and fined, the money for cash of posyandu. This agreement needs to be expected that initially compulsory trials will become a habit, if posyandu advanced which is indicated by high attendance level of pregnant mother and toddler this can support government policy that is "Healthy Village".

Low attendance motivation is caused by several things, including mothers who leave for work, feel the baby is healthy so do not need to be examined, less concerned with the presence of posyandu. Therefore, the increased attendance motivation to posyandu needs to be improved to support government programs to improve the public health index through programmable vaccination movement, so that the community is free from endemic diseases such as smallpox, diphtheria, polio, hepatitis and so on.

The discrepancy between their current developmental levels and what they would have achievedin a more nurturing environment with adequate stimulation and nutrition indicates the degree of loss ofpotential. In later childhood these children will subsequently have poor levels of cognition and education,both of which are linked to later earnings. Furthermore,improved parental education, particularly of mothers, isrelated to reduced fertility,2,3 and improved child survival health, nutrition, cognition, and education [3].

Nutrient deficiency and experiential input from the environment may have independent additive effects on brain development. In this case, in anat-risk population, one would expect children with bothrisk factors (nutrient deficiency and low stimulation) to perform at low levels, children with one risk factor(nutrient deficiency or low stimulation) to perform ataverage levels, and children with neither risk factor (sufficientnutrition and high stimulation) to perform athigh levels in cognitive, motor, and socioemotional development. Insupport of this hypothesis, several studies have shown that nutritional supplementation and psychosocial stimulation together result in greater improvements inchild development than either intervention alone.49,50 In these studies, psychosocial stimulation consisted of periodichome visits during which community workers facilitated play sessions with mothers and children. The community workers conducted activities such as demonstrating play with homemade toys, emphasizing the quality of the verbal interactions between mothers and children, and teaching concepts such as color, shape,size, and number [2].

\section{E. Analysis of Knowledge Improvement and Skills of Training Participants}

Increased post-training knowledge is measured through pre test and post test.Pre test is given before the training activity of improvement of child's growth knowledge, by means of each participant is given questionnaires to be filled in accordance with known basic knowledge, questionnaire consists of 30 questions are 10 questions about brain growth, 10 questions about baby's body growth and the last 10 questions about the MPASI . The average result of pre test value is 43,57 while average post test result is 76,28 so there is increase of knowledge equal to $32,71 \%$. Increased knowledge is not as large as targeted, this is because the academic atmosphere is less supportive. Too many participants, should be divided into 2 or 3 classes to be more comfortable and concentrated, while during the demo processing of filtered foods, soft foods and peanuts cookies, the participants are very enthusiastic shown, many serious participants pay attention, record and ask the resource person.

\section{F. Maintaining the Integrity of the Specifications}

The template is used to format your paper and style the text. All margins, column widths, line spaces, and text fonts are prescribed; please do not alter them. You may note peculiarities. For example, the head margin in this template measures proportionately more than is customary. This measurement and others are deliberate, using specifications that anticipate your paper as one part of the entire proceedings, and not as an independent document. Please do not revise any of the current designations. 


\section{CONCLUSIONS}

Based on the results and discussion can be concluded:1) Need assessment with $\mathrm{Q}$ short method is very practical to determine the problems of trainees, 2) Generated 3 main problem for posyandu manager that is knowledge of toddler growth, food processing of MPASI and discipline pregnant mother and toddler to come to posyandu, 3). There is an increase of knowledge and skill of the posyandu manager by $32,71 \%$ so that it can be used to answer the problem in management of posyandu. The suggestion is posyandu management is the spearhead of communitydevelopment, continuous knowledge and skill improvement is very important so that the development of pregnant and toddler problems can be handled temporarily, waiting for the handling from resource persons that is Doctor or local midwife.

\section{REFERENCES}

[1] Steyn, N. Nel, J. Nantel, G. Kennedy, G. and Labadarios, D. "Food variety and dietary diversity scores in children: are they good indicators of dietary adequacy?," Public Health Nutrition, vol. 9(05), pp. 644-650, 2006.

[2] Prado, E. L. and Dewey, K. G. "Nutrition and brain development in early life," Nutrition Reviews, vol. 72(4), pp. 267-284, 2014.
[3] Grantham-mcgregor, S. Cheung, Y. B. Cueto, S. Glewwe, P. Richter, L. and Strupp, B. "Child development in developing countries 1 Developmental potential in the fi rst 5 years for children in," Lancent, 369, 60-70, 2007.

[4] Johnson, S. B. Riis, J. L. and Noble, K. G. "State of the Art Review: Poverty and the Developing Brain," Pediatrics, vol. 137(4), pp. e20153075-e20153075, 2016.

[5] Gandhel C. and Simon C., 1996. Body and Helth, Tokyo : Tokyo University of Education

[6] Nyaradi, A. Li, J. Hickling, S. Foster, J. and Oddy, W. H. "The role of nutrition in children's neurocognitive development, from pregnancy through childhood," Frontiers in Human Neuroscience, vol. 7, pp. 1-16, March 2013.

[7] Rose-Jacobs, R. Black, M. M. Casey, P. H. Cook, J. T. Cutts, D.B. Chilton, M. and Frank, D. A. "Household Food Insecurity: Associations With At-Risk Infant and Toddler Development," Pediatrics, vol. 121(1), pp. 65-72, 2008.

[8] Bayu, M, Pintar Asi dan Menyusui. Jakarta: Panda Media, 2014.

[9] Nataliningsih, Pengembangan Model Penyuluhan Pertanian Partisipatif bagi Kelompok Tani Pemula. Bandung : Universitas Pendidikan Indonesia, 2009.

[10] Nataliningsih, Buku Ajar : Gizi dan Diet, Bandung : Akademi Tata Boga Bandung, 2014.

[11] Allen, R. E and Myers, A. "Nutrition in Toddlers," American Family Phycisian, vol. 74(9), 2006.

[12] Krebs, N. F. "Food choices to meet nutritional needs of breast-fed infants and toddlers on mixed diets," The Journal of Nutrition, vol. 137, pp. 511S-517S, February 2007. 